\title{
THE POSITIVE REALITY AND NORMATIVE VIRTUES OF A "NEUTRAL" ESTABLISHMENT CLAUSE
}

\section{Arnold H. Loewy*}

Establishment Clause cases are typically animated by three somewhat overlapping yet contradictory concepts: separation, accommodation, and neutrality. The cases themselves are primarily divided into two major categories: cases involving deific recognition (such as school prayer) and cases involving government financing of religious entities, particularly Parochial Schools.

Cases involving deific recognition are rarely decided on grounds of separation. ${ }^{1}$ Usually the battle is between neutrality, the guiding principle of School District of Abington v. Schempp, ${ }^{2}$ and accommodation, which drives the opinions of Zorach v. Clauson ${ }^{3}$ and Lynch $v$. Donnelly. ${ }^{4}$ In this area, separationists typically align themselves with those that support neutrality.

Cases involving government financing of religion have a different battleground. There, cases tend to be decided on strict separation grounds as in Lemon v. Kurtzman, ${ }^{5}$ or in accordance with principles of neutrality. ${ }^{6}$ Of course, here accommodationists join forces with those who support neutrality. Thus, for many in the field, the propriety of neutrality depends on whether it is perceived to help or hurt government's capacity to benefit religion.

It is the thesis of this Article that in both the Deific recognition and government financing cases, the Court is moving towards neutrality as its presumptive standard. A further thesis is that this is a good thing and probably

* Graham Kenan Professor of Law, The University of North Carolina at Chapel Hill School of Law. I am grateful for the dedicated research assistance of William Cross.

1 But cf. Ill. ex rel McCollum v. Bd. of Educ., 333 U.S. 203, 213 (1948) (which at least invoked the concept. The decision itself was certainly consistent with principles of neutrality).

2374 U.S. 203 (1963).

3343 U.S. 306 (1952).

4465 U.S. 668 (1984) (at least the plurality).

5403 U.S. 602 (1971).

6 See, e.g., Mitchell v. Helms, 530 U.S. 793 (2000) (plurality opinion). 
should be accelerated. I will begin by evaluating the relative merits of separation, accommodation, and neutrality.

\section{SEPARATION}

A separationist seeks to erect "a wall between church and State ... high and impregnable." Of course absolute separation is impossible. For example, Everson, which gave us the "wall" metaphor, allowed, to the dismay of the dissenters, parochial school children to ride a bus at taxpayer expense. ${ }^{8}$ But even the dissenters agreed that police and fire protection was available to the Church, and not just on the theory that it may be necessary to quench a church fire in order to keep it from spreading to secular property. ${ }^{9}$ Thus, all would agree that complete and total separation is not possible.

But there are those who would like to maximize separation at every turn. For the most part this viewpoint dominated the landscape during the 1970s in regard to public funding of parochial education. In the landmark Lemon case, for example, the Court invalidated a supplement to the secular teachers in religious schools on the ground that any infusion of religion by a partially subsidized teacher would violate the Establishment Clause. ${ }^{10}$ Furthermore, even a school's promise not to infuse religion was thought to be inadequate because without monitoring, there was always the possibility of intentional or unintentional infusion. ${ }^{11}$ Finally, the necessary monitoring was thought to create excessive entanglement between Church and State. ${ }^{12}$

Of course, if the Court had used a neutrality standard, nobody would have cared if the teacher had injected religion so long as she had provided the school with its secular money's worth. Under a neutrality standard, if the cost to the State of teaching a child English in a parochial school was no more than it would have expended on that child in a public school (or secular private school), it is hard to see how the State financed religion. In a worse case scenario, the State merely financed English and failed to prevent religion from being taught at no extra cost.

Everson v. Bd. of Educ., 330 U.S. 1, 18 (1947).

Id. at 17.

9 Id. at 61 - 62 (Rutledge, J., dissenting).

10403 U.S. 602 (1971).

11 Id. at 616.

12 Id. at 619. 
Separationist theory has had a considerably more checkered history in regard to tax exemptions and deductions. Although a tax exemption for churches has been approved, largely on a neutrality theory, ${ }^{13}$ tax deductions for a parochial school education were disapproved in the 1970s. ${ }^{14}$ Strangely, nobody has successfully challenged charitable deductions for contributions to a church. Thus, if one contributes $\$ 1,000$ to a church, and as part of that contribution is able to educate one's child in religion, the deduction is probably valid. ${ }^{15}$ But if one pays $\$ 1,000$ to the church to educate her child in English and math, the tuition may not be deductible. To one not steeped in the intricacies of Establishment Clause jurisprudence, this dichotomy must seem perverse.

\section{ACCOMMODATION}

An accommodationist is willing to allow government to treat religion better than non-religion in some particulars. When this is done to alleviate a burden on free exercise of religion, such as allowing Native Americans to smoke peyote,${ }^{16}$ or allowing ceremonial use of wine in an otherwise dry county, ${ }^{17}$ few would seriously challenge the practice. ${ }^{18}$ However, there is a significant school of thought that would allow the government to accommodate religion even when free exercise is in no way compromised.

13 See Walz v. Tax Comm'n, 397 U.S. 664 (1970) (where a New York tax exemption for property "used exclusively for ... religious purposes" was upheld as constitutional. The Court based this conclusion in part on the comparable tax treatment afforded similar non-religious entities such as benevolent associations.).

14 See Comm. for Pub. Educ. and Religious Liberty v. Nyquist, 413 U.S. 756 (1973). But cf. Mueller v. Allen, 463 U.S. 388 (1983).

15 I say probably because there has been no case specifically upholding it. But there has been lots of dicta. See, e.g., Witters v. Wash. Dept. of Servs. for the Blind, 474 U.S. 481, $487-$ 90 (1986); Mueller v. Allen, 463 U.S. 388, 397-400 (1983). See also School Dist. of Abington v. Schempp 374 U.S. 203, 302 (Brennan, J., concurring).

16 See, e.g., Employment Div. v. Smith 494 U.S. 872, 890 (1990). See also the Oregon (OR. REV. STAT. \$475.992 (2001)) and Federal (42 U.S.C. \$1996a (West 2002)) statutory responses thereto.

17 See, e.g., Church of the Lukumi Babalu Aya, Inc. v. City of Hialeah, 508 U.S. 520, 561 n.2 (1993) (Souter, J., concurring).

18 But see City of Boerne v. Flores, 521 U.S. 507, 536-37 (1997) (Stevens, J., concurring) (suggesting that religious accommodation violates the Establishment Clause. No other current Supreme Court Justice would concur.). 
Zorach v. Clauson ${ }^{19}$ originated the concept in an opinion upholding the early dismissal of those public school students who chose to attend religious classes outside of school. The Court believed that a contrary decision would constitute a "callous indifference" to religion. ${ }^{20}$ Thus, the Court allowed the school to suspend learning, while detaining students not receiving religious training, in order to facilitate the religious training of the released students. ${ }^{21}$

The Court has also upheld legislative prayer ${ }^{22}$ and the display of a cityowned crèche in a Christmas display. ${ }^{23}$ And, perhaps most perniciously, has implied that a whole host of seemingly minor paeans to the Deity are constitutionally permissible under the rubric of "ceremonial Deism." ${ }^{24}$ Included in these are the Supreme Court's opening invocation "May God save the United States and this honorable Court," the phrase "In God we trust" on our coins and currency, and the phrase "under God" in the flag salute. ${ }^{25}$

\section{NEUTRALITY}

The phrase "neutrality" first prominently appeared in our Establishment Clause jurisprudence in the school prayer cases, ${ }^{26}$ particularly Schempp, where the Court described it as "wholesome neutrality."27 Of course, whether a particular decision invalidating legislation designed to favor religion is "wholesome neutrality" or "callous indifference" depends largely on the emotional state of mind of the evaluator. Either term could have been used to describe the invalidation of the bible reading statute at issue in Schempp. For that matter, either term could have been applied to the opinion of the four Justices who sought to invalidate the Zorach practice. The key is to find a meaningful principle.

19343 U.S. 306 (1952).

20 See id. at 314 (presumably as opposed to "wholesome neutrality" towards religion. See also Abington School Dist. v. Schempp 374 U.S. 203, 222 (1963)).

21 See id.

22 See Marsh v. Chambers, 463 U.S. 783 (1983).

23 See Lynch v. Donnelly, 465 U.S. 668 (1984).

24 See Lynch, 465 U.S. at 716 n.24 (The development of this term is usually attributed to Dean Eugene Rostow from a 1962 Meikeljohn lecture). See infra Part VII.

25 The latter of course has recently come under more exacting scrutiny from the Ninth Circuit in Newdow v. U.S. Congress, 292 F.3d 597 (9th Cir. 2002). I will discuss this issue in more detail in Part VII, infra.

${ }^{26}$ See School Dist. of Abington v. Schempp, 374 U.S. 203 (1963); Engel v. Vitale, 370 U.S. 421 (1962).

27374 U.S. at 222. 
In my mind, Justice O'Connor's much maligned endorsement/disapproval test would, if taken seriously, ${ }^{28}$ provide a viable standard for deciding Establishment Clause cases. The test has been maligned on at least two grounds. One suggests that it does not accurately portray the Court's actual decision-making process. $^{29}$ The other critique is that it is incapable of achieving certainty because those who apply it do not always reach the same result. $^{30}$ As to the first criticism, it probably is correct that the Court does not always apply the endorsement/disapproval test in a serious way. But, it is the contention of this paper that it ought to. As to results varying under the test, that is true of most any test. There will always be close cases upon which reasonable people applying the same test might reach different results. ${ }^{31}$

The core of the endorsement/disapproval test is that it precludes disfavoring religion as much as favoring it. Although some argue that disapproval belongs with free exercise rather than establishment, ${ }^{32}$ I think this criticism misses the mark. It is no part of the Establishment Clause to be hostile to religion in any way. The line of decisions, culminating with Good News Club v. Milford Central School, ${ }^{33}$ that emphasize the impropriety of treating religion less

28 See Arnold H. Loewy, Rethinking Government Neutrality Towards Religion Under the Establishment Clause: The Untapped Potential of Justice O Connor's Insight, 64 N.C. L. REV. 1049 (1986).

29 See Allegheny v. ACLU 492 U.S. 573, 670 (Kennedy, J., dissenting).

30 See Steven D. Smith, Symbols, Perceptions, and Doctrinal Illusions: Establishment Neutrality and the "No Endorsement" Test, 86 Mich. L. REv. 266, 301 n.75 (1987).

31 For example, Supreme Court Justices have reached different results in the same factpattern under the Commerce Clause and several Fourth Amendment standards. See, e.g., United States v. Morrison, 529 U.S. 598, 601, 655 (2000) (Chief Justice Rehnquist and Justice Breyer similarly reaching differing results using the "substantial effect on commerce among the several states" test); Illinois v. Wardlow, 528 U.S. 119, 121,126 (2000) (compare Chief Justice Rehnquist and Justice Stevens in a reasonable suspicion case); Illinois v. Gates, 462 U.S. 213, 216, 219 (1983) (Justice Rehnquist and Justice Stevens on a probable cause issue); Vale v. Louisiana, 399 U.S. 30, 31, 36 (1970) (Justices Stewart and Black in an exigent circumstances case). Despite the differing results reached by reasonable people in these cases, all of these tests are accepted as valid and useful.

32 See, e.g., Douglas Laycock, Towards a General Theory of the Religion Clauses: The Case of Church Labor Relations and the Right to Church Autonomy, 81 COLUM. L. REV. 1373, 1380-85 (1981).

33533 U.S. 98 (2001). See also Lamb's Chapel v. Ctr. Moriches Union Free Sch. Dist., 508 U.S. 384 (1993); Bd. of Educ. v. Mergens, 496 U.S. 226 (1990); Widmar v. Vincent, 454 U.S. 263 (1981). 
favorably than other entities, are especially important. When juxtaposed with the school prayer cases, ${ }^{34}$ they put real teeth into the concept of neutrality. ${ }^{35}$

The one relatively recent school case in which the Court failed to use the neutrality test was Edwards $v$. Aguillard, in which the Court invalidated a law designed to accord scientific creationism equal time with evolution. ${ }^{36}$ At the relevant stage of the case, the State had not yet been allowed to present its case for the scientific validity of creationism. It was enough for the Court that the legislature had a religious purpose in enacting the legislation. ${ }^{37}$ Thus, even if the scientific evidence supporting creationism were valid, ${ }^{38}$ the legislation would be invalid because of the legislative motivation. This is not neutrality. ${ }^{39}$

\section{THE THREE TESTS IN ONE CASE}

In Capital Square Review and Advisory Board v. Pinette, the Ku Klux Klan wished to place a cross in an otherwise public forum at Christmas season. ${ }^{40}$ The Court was faced with the question of whether Ohio could selectively deny religious symbols in a public square on the ground that a passersby might conclude that the State endorsed religion. Two of the Justices, focusing on principles of separation, would have allowed the Klan's cross to be excluded. ${ }^{41}$ In their view, the mere possibility that a passerby would perceive the government to have favored religion was enough to uphold the exclusion. ${ }^{42}$

34 See, e.g., School Dist. of Abington v. Schempp, 533 U.S. 98 (2001); Santa Fe Ind. School Dist. v. Doe 530 U.S. 290 (2000); Lee v. Weissman, 505 U.S. 577 (1992).

35 Of course it is possible to read cases such as Good News as simply not allowing the Establishment Clause to trump the Free Speech Clause. But I believe that those cases would, or at least should, be decided the same way if we had no Free Speech or Equal Protection Clause and had to rely entirely on the Establishment Clause.

36482 U.S. 578 (1987).

37 See id. at 590.

38 A highly unlikely event.

39 As an example of the fatal flaws in this test, imagine that a pre-Columbus (1492) teacher were attempting to teach that the world was round (rather than flat), in accordance with the beliefs of a religion called "The Round Earth Religious Society." Such teachings would have been disallowed because of their religious support, notwithstanding their subsequently proved scientific correctness.

40515 U.S. 753, 758 (1995).

41 See id. at 797, 817 (Stevens, J., dissenting and Ginsburg, J., dissenting).

42 See id. 
Four other Justices would have allowed the display on the ground that even if religion appeared to be favored, that was a nonproblematic accommodation. ${ }^{43}$

The case was ultimately decided on neutrality grounds by Justices O'Connor, Breyer, and Souter who held that so long as a reasonable person would not perceive the government to be endorsing religion, neutrality principle required that the cross be allowed. ${ }^{44}$ In my view, these Justices got it absolutely right.

\section{NEUTRALITY AND THE FINANCING OF PAROCHIAL EDUCATION}

There is little doubt that the Court is moving towards neutrality in the financing of parochial education cases. One need only briefly contrast Zelman v. Simmons-Harris ${ }^{45}$ and Mitchell v. Helms ${ }^{46}$ with Lemon $^{47}$ and Nyquist ${ }^{48}$ to see how far from separation and towards neutrality the Court has moved. Four Justices are firmly in the neutrality camp, ${ }^{49}$ and $\mathrm{O}^{\prime}$ Connor, while eschewing that rhetoric, is not very different in substance. ${ }^{50}$

On the whole, this is a good thing. No serious scholar has ever contended that the Establishment Clause was intended to bespeak hostility towards religion. Yet that is exactly what happens in a regime that allows the State to pay a student's tuition or an English teacher's salary at a private nonreligious school, but denies the same to students and teachers at a private religious school.

My only hesitancy in reaching this conclusion is the possibility that in some cities, public schools will be so bad that a student would opt for any affordable alternative. To the extent that a City, such as Cleveland in Zelman, makes funds available to a religious school as the only realistic alternative to a bad

43 See id. at 757 (opinion of Scalia, J., joined by Rehnquist, Kennedy, and Thomas). See also id. at 770 (Thomas, J., concurring) (arguing that the cross, in this context, was political and not religious).

44 See id. at 772, 783 (O'Connor and Souter, JJ., separate concurring opinions, both joined by Breyer, J.).

45536 U.S. 639 (2002).

46530 U.S. 793 (2000).

47403 U.S. 602 (1971).

48413 U.S. 756 (1973).

49 See Mitchell, 530 U.S. at 801 (Scalia, J., joined by Rehnquist, C.J., and Thomas, Kennedy, JJ.).

50 See Zelman, 536 U.S. at 623 - 32 (O'Connor, J., concurring); Mitchell, 530 U.S. at 836 (O’Connor, J., concurring). 
public school, I am concerned. For example, let us hypothesize that for a particular Baptist (or Jewish or Atheist) student in a poor section of town, her two realistic choices are public school (which is terrible) and Catholic School (which is much better, but requires religious exercises with which the student is uncomfortable). Such a student may well feel driven by the State to accept an . intolerable religion in order to obtain an acceptable education.

Although the above scenario is problematic, I do not believe that it is unconstitutional. Without State vouchers, the hypothetical student has one bad choice, the public school. With the voucher, she has two bad choices: the public school or the school espousing the wrong religion. Given that the student makes the choice (and can still opt for the bad public school that she would have in the absence of a choice), I believe that the statute was rightly upheld. Perhaps with evidence that students in large numbers were being effectively forced into schools of a different religion from their own, it might be appropriate to rethink complete neutrality. But, absent such evidence, neutrality appears to be a viable principle.

\section{NEUTRALITY AND DEIFIC RECOGNITION}

The move towards neutrality (and away from accommodation) is not so clear in the deific recognition cases, but it is discernible. One need only compare the tone of the Lee $v$. Weisman ${ }^{51}$ opinion with the later opinion in Santa Fe Independent School District v. Doe. ${ }^{52}$ In Lee, the Court very cautiously invalidated a graduation prayer at a middle school delivered by a clergyman. ${ }^{53}$ In so holding, the Court emphasized the special importance of graduation to the students and the coercive character of prayer to nonbelievers. The four Justice dissent, advocating accommodation, was extraordinarily vitriolic even by Justice Scalia's standards. ${ }^{54}$

51505 U.S. 577 (1992).

52530 U.S. 290 (2000).

53 See Lee, 505 U.S. at $598-99$.

54 See id. at 631 - 66. Justice Scalia dubbed Lee a "jurisprudential disaster" that adopted a "psycho-coercion test, which suffers the double disability of having no roots whatever in our people's historic practice, and being as infinitely expandable as the reasons for psychotherapy itself." Id. at 644. He continues his invective, charging that "[a]s its instrument of destruction, the bulldozer of its social engineering, the Court invents a boundless, and boundlessly manipulable, test of psychological coercion, which promises to do for the Establishment Clause what the Durham rule did for the insanity defense." Id. at 632. Justice Scalia follows with more assertions that Lee "is, not to put too fine a point on it, incoherent." Id. at 636. However, 
Santa $\mathrm{Fe}$, on the other hand, invalidated a student-led prayer at a football game, a place where it would have been relatively easy for students to ignore the prayer. The tone of the opinion seemed to reflect impatience with the school district for not understanding the importance of remaining neutral on deific issues. The dissent, on the other hand, was rather placid, almost resigned to a view that official deific recognition in schools will be unconstitutional so long as the current Court sits. ${ }^{55}$

Cases demanding neutrality as opposed to disapproval are moving in the same direction. From Board of Education of Westside Community Schools $v$. Mergens, ${ }^{56}$ to Lamb's Chapel, ${ }^{57}$ to Good News, ${ }^{58}$ the Court's opinions are increasingly emphasizing the impropriety of disfavoring religion. Of course, the difference in the cases is that Santa $\mathrm{Fe}$ singles out religion for special favored treatment, whereas Good News merely allows religion to compete for space along with everything else. Although we are talking about the center of the Court, ${ }^{59}$ the center does seem to take neutrality seriously in regard to deific recognition in schools.

\section{CEREMONIAL DEISM}

Ceremonial Deism is an annoying and pernicious phrase first brought into judicial decisions by Justice Brennan. ${ }^{60}$ It is thought to justify phrases such as

he cheerfully concludes by suggesting a way for religiously-minded schools to thwart this decision so that "the graduates and their parents may proceed to thank God, as Americans have always done, for the blessings He has generously bestowed on them and on their country." Id. at 645 .

55 Of course, the dissent was written by Chief Justice Rehnquist rather than Justice Scalia. Stylistically, the Chief Justice's opinions generally are not so vitriolic as Justice Scalia's. But see Texas v. Johnson, 491 U.S. 397, 421 (1989) (Rehnquist, J., dissenting).

56496 U.S. 226 (1990).

57508 U.S. 384 (1993).

58533 U.S. 98 (2001).

59 Justices Stevens and Souter (joined by Ginsburg, J.) dissented in Good News, believing that a public school is free, at least some of the time, to discriminate against religion. 533 U.S. at 131. Chief Justice Rehnquist, along with Justices Scalia and Thomas, dissented in Santa Fe, believing that a public school is free, at least some of the time, to discriminate in favor of religion. 530 U.S. at $322-23$.

${ }^{60}$ See Lynch v. Donnelly, 465 U.S. 668, 716 n.24 (1984) (Brennan, J., dissenting). The first known use of the phrase was by Dean Eugene Rostow. See Arthur E. Sutherland, Book Review, 40 IND. L.J. 83, 86 (1964) (quoting Dean Rostow's 1962 Meikeljohn Lecture delivered at Brown University). 
"In God We Trust" on our coins and "May God save the United States and this honorable Court" to begin Supreme Court sessions. ${ }^{61}$

It is doubtful that any litigant would have standing to challenge either of these practices although an atheist litigating a question before the Supreme Court against a Christian would certainly feel at disadvantage. ${ }^{62}$ Do we or should we care that these public paeans to the Deity continue unabated (and arguably unabatable)? My answer is that we should care because phrases such as these clearly endorse much of our citizenry while disapproving a minority that should not have to tolerate it. ${ }^{63}$ But sadly, the majority likes the endorsement so much, that there would be hell to pay ${ }^{64}$ if we were to remove it.

A good example is the recent flap over the Ninth Circuit's Newdow decision. ${ }^{65}$ Although correctly decided for the reasons described in my appended editorial, ${ }^{66}$ the flap over the decision has rivaled that of the flag burning and school prayer cases combined. Of course, to the shallow viewer, Newdow is an attack on God and country. To the more sophisticated critic, it is an attempt to put each in its proper sphere. Newdow, were it to be affirmed by the Supreme Court, would ensure that nobody is put in the position of having to feign Godliness to avoid being condemned as unpatriotic. Furthermore, it would continue the Court on the march toward neutrality that its recent jurisprudence has so carefully developed.

\section{CONCLUSION}

Ordinarily, neutrality is a sound starting point for Establishment Clause jurisprudence. It avoids the potentially harsh concept of separation which too frequently treats religious institutions as second class citizens. It also avoids the mushiness of accommodation which, at times, treats nonbelievers as second

61 Part of the Court's willingness to accommodate religion in Zorach v. Clauson, 343 U.S. 306 (1952), was its fear that otherwise "[a] fastidious atheist or agnostic could even object to the supplication with which the Court opens each session: 'God save the United States and this Honorable Court." Id. at 313.

62 See Loewy, supra note 28, at 1058.

63 See id. at 1057. See also Steven B. Epstein, Rethinking the Constitutionality of Ceremonial Deism, 96 COLUM. L. REv. 2083 (1996).

64 Excuse the somewhat religious expression.

65 Newdow v. U.S. Congress, 292 F.3d 597 (2002). Modified, _F.3d_(2003). Modified, and hearing en banc denied, 321 F.3d 772 (2003).

${ }^{66}$ See appendix A. 
class citizens. Neutrality does, in fact, seems to be the direction in which the Court is headed. It is a trend that should be accelerated. 